\title{
A LEGISLAÇÃO EDUCACIONAL PARAENSE E O PROJETO LIBERAL CIVILIZADOR: ENTRE DISCURSOS E PRÁTICAS (1841-1870)
}

\author{
Dércio Pena Duarte ${ }^{2}$ \\ Silvio Sánchez Gamboa ${ }^{3}$
}

\section{RESUMO}

Como forma de compreender as relações entre as condições materiais de uma sociedade e os discursos que circulam em seu entorno, este artigo busca analisar parte da legislação educacional produzida no Pará entre os anos de 1841 e 1870, no período do Segundo Reinado. Buscamos confrontar estas leis com discursos nos quais se evidencia a importância da instrução pública como elemento de progresso e civilização de um povo, sustentada como ideia universal e consensual. De fato, tais discursos são marcados pelo ideário liberal predominante entre políticos e intelectuais brasileiros daquele período, entendidos como reflexo da inserção do Pará e do Brasil no contexto do capitalismo internacional e sua busca por se adequar a este novo contexto.

Palavras-chave: instrução pública; liberalismo; província do Grão-Pará.

\section{ABSTRACT}

In order to understand the relationship between the material conditions of society and the discourses that are spread around it, this article seeks to analyze part of the educational legislation produced in Pará between the years 1841 and 1870, at Brazilian Second Empire. We seek to confront these laws with speeches in which it highlights the importance of public education as element of progress and civilization of a people, sustained as a universal and consensual idea. In fact, such speeches are marked by the prevailing liberal ideology among Brazilian politicians and intellectuals of the period, understood because of insertion of Pará and Brazil in the context of international capitalism and its quest to suit this new context.

Keywords: public education; liberalism; Grão-Pará province.

\section{Introdução}

A educação tem sido referida em diversas ocasiões como forma de solucionar e prevenir problemas sociais, econômicos e políticos. Garantir o acesso de todas as pessoas à escola e assegurar sua permanência e aproveitamento com qualidade parece indicar um caminho através do qual todas as nações poderiam superar os obstáculos ao seu pleno desenvolvimento e atingir o mais alto nível de suas potencialidades. Diz-se que através da educação se pode alcançar a cidadania, e a formação de cidadãos é considerada uma das prioridades do processo educativo, tendo como uma das principais características a valorização de conhecimentos práticos e úteis ao cotidiano dos alunos, em detrimento da memorização pura de conceitos e ideias a serem reproduzidos nas avaliações escolares. Educar para a cidadania é uma meta comum a vários projetos político-pedagógicos das escolas brasileiras, talvez mais pelo impacto que o modismo desta ideia representa que pela efetividade das ações escolares que visam este fim. 
Carlota Boto (1996) comenta sobre a distância que existe entre a importância da educação nos discursos oficiais e as poucas ações concretizadas de acordo com esta preocupação, apontando estes elementos discursivos como "retórica de palanque", uma vez que não se refletem na realidade do sistema educacional. Uma vez que políticos e formadores de opinião assumiram tais discursos para si, não é de se estranhar que, apesar da unanimidade da importância da educação escolar para um país, as medidas apresentadas para sua adequação e aproveitamento de seu potencial diferem bastante entre si, orientadas por diversas nuances ideológicas e particularidades políticas. Nesta miríade ideológica que orienta discursos e práticas, o caráter liberal da educação brasileira como um todo predomina, apresentando problemas e soluções para o panorama educacional orientados por conceitos como cidadania, qualidade de ensino, eficiência e qualificação. Estas são ideias que evocam metas universais a serem atingidas pelos diversos sistemas educacionais nacionais, avaliadas por programas de avaliação que contam com a legitimação de organizações internacionais ligadas a grandes grupos financeiros.

Percebemos que a permanência do discurso que exalta a educação como elemento fundamental para a solução dos problemas de um país pode ser compreendida a partir de sua origem, especialmente quando tratamos de concepções pedagógicas adotadas pelas autoridades em consonância aos interesses das elites econômicas e sociais. No caso do Brasil, quando os jesuítas perderam o monopólio do ensino em Portugal e suas colônias no século XVIII, a partir das reformas implantadas pelo Marquês de Pombal, o ensino subsidiado pelo Estado, através primeiramente das Aulas Régias, buscou se afastar dos fundamentos do ensino jesuítico, em especial nas matérias referentes às Letras Clássicas (grego e latim) e à Retórica, e implantar matérias de caráter prático, como noções de comércio e escrituração contábil, desenho geométrico, aritmética e geografia. Com isso, a laicidade do ensino ganhava contornos nítidos e passaria a caracterizar um dos principais motivos da defesa liberal da instrução pública. Sob influência do Iluminismo do século XVIII e antecipando algumas das ideias do positivismo do final do século XIX, políticos e intelectuais de tendência liberal cobravam do governo a oferta de uma instrução universal, desvinculada da Igreja Católica e abrindo espaço para outras manifestações de fé cristã, como a desobrigação da frequência e avaliação das aulas de ensino religioso aos não católicos.

Chama a atenção a atualidade dos discursos que vinculam a educação ao progresso de uma nação, seja no sentido social, econômico, cultural e político. Apesar das várias décadas que separam o período analisado e a atualidade, vários elementos permanecem semelhantes, como a insistência no caráter "redentor" da educação para a solução das mazelas sociais. Como produtos de uma sociedade imersa em um tempo sob condições materiais específicas, tais discursos têm contornos intrínsecos, que os diferenciam dos discursos produzidos sob outras condições. Porém, ao considerarmos o tempo histórico como um continuиm entre passado, presente e futuro, cujas articulações entre si constituem uma superestrutura que encerra em si todas as relações sociais e econômicas de um período e, consequentemente, todo pensamento produzido e divulgado, não é possível tratá-los como atemporais, sendo antes necessário compreender a permanência das condições que validam estes discursos na atualidade. Portanto, analisar as condições de produção dos discursos sobre educação em meados do século XIX é relevante para se compreender em que sentido sua permanência na atualidade representa a manutenção de uma estrutura social semelhante à daquela época. 
No sentido de entender como os discursos possibilitam acessar a estrutura social da época na qual foram emitidos, apoiamo-nos em Marx e Engels (2007) quando afirmam que a relação primária que a constitui é a que se estabelece entre a natureza e o ser humano, a partir das bases naturais e das modificações humanas sobre estas bases ao longo do tempo. Ao produzirem seus meios materiais de existência, os seres humanos tanto reproduzem os meios já elaborados pela natureza ou por seus antepassados, quanto criam novos meios condicionados por seu modo de vida e que por fim condicionam esta vida também. Com isso, os indivíduos são determinados pelos modos de vida, mais especificamente modos de produção, vigentes em seu tempo, o que inclui suas relações sociais, relações políticas, leis, edificações, ciência, religião e ideias em geral. Sob esta compreensão do ser humano como ser histórico circunscrito às condições materiais de seu tempo, buscamos através das fontes a manifestação da realidade da instrução pública na província paraense de meados do século XIX pelas falas e escritos dos homens viventes naquele local e período. No entanto, para evitar equívocos com uma concepção positivista de história na qual a realidade é tal e qual as fontes a apresentam, vale lembrar como Marx e Engels diferenciam o homem real do homem representado abstratamente:

Contrariamente à filosofia alemã, que desce do céu para a terra, aqui parte-se da terra para atingir o céu. Isto significa que não se parte daquilo que os homens dizem, imaginam e pensam nem daquilo que são nas palavras, no pensamento, na imaginação e na representação de outrem para chegar aos homens em carne e osso; parte-se dos homens, da sua atividade real. É a partir do seu processo de vida real que se representa o desenvolvimento dos reflexos e das repercussões ideológicas deste processo vital. (MARX \& ENGELS, 2007, p. 126)

Apoiamo-nos em tal perspectiva ao compreendermos que as fontes analisadas são representações feitas pelos indivíduos acerca do objeto investigado e das categorias analíticas que adotamos, e que podemos compreender tais representações a partir das condições materiais de existência daqueles indivíduos, em um período no qual o Brasil mantinha um sistema econômico predominantemente agrário e escravista ao mesmo tempo em que se inseria no capitalismo industrial internacional como fornecedor de matériaprima e mercado consumidor dos excedentes da superprodução de países industrializados. Assim, ao situarmos as fontes no contexto social, político, econômico e cultural em que foram produzidas, chegamos em última instância ao homem real, para além das concepções que faz sobre si e sobre o mundo.

Sob estas prerrogativas, buscamos neste artigo, como apresentação parcial dos resultados de uma tese de doutorado recentemente defendida, analisar a legislação referente à instrução pública na província do Grão-Pará no período entre 1841 e 1870. Promovemos diálogos entre as leis investigadas e discursos sobre educação proferidos por autoridades e intelectuais daquele tempo e espaço, visando articular as proximidades e contradições entre o ideário liberal que orientava as políticas educacionais brasileiras no século XIX e as condições locais de um território extenso e economicamente fundamental na Amazônia. Com isso, pretendemos demonstrar que a adoção de discursos liberais em relação à defesa da instrução pública repercutiu entre a intelectualidade paraense como reflexo da importância de se elevar a província a um patamar civilizado que a permitisse se inserir plenamente no sistema capitalista internacional do período. Primeiramente, faz-se necessário compreender o contexto social, econômico e político do período em estudo, especialmente no que diz respeito ao Brasil e à província do Pará. 


\section{Breve contextualização do período}

A industrialização das nações europeias foi a pedra de toque do poder político e econômico que exerciam no período entre 1840 e 1870, quando o mundo experimentou o ápice do liberalismo econômico, ao mesmo tempo impulsionando o desenvolvimento industrial e por ele impulsionado. Um dos maiores impulsos à crescente industrialização foram os avanços técnicos nos meios de produção e de comunicação, com especial desenvolvimento da química e da elétrica na segunda metade do século XIX. Esta intensa relação entre ciência e indústria resultaria na crescente importância do sistema educacional para o desenvolvimento industrial, de modo que, na década de 1870, países industrializados com taxas de escolaridade baixas, como França, Bélgica e Inglaterra, se desenvolveriam mais lentamente em relação a países menos industrializados cujos cidadãos possuíam maior escolaridade, como a Suécia (HOBSBAWM, 2012). Entretanto, uma educação eminentemente técnica e sistemática voltada diretamente ao trabalho industrial somente prevaleceria na Europa ao final do século XIX, enquanto os Estados Unidos investiram na formação de engenheiros em instituições de alta qualidade desde meados daquele século, o que respondeu em parte pelo acelerado crescimento da indústria americana. Não se tratava, pois, de associar a educação formal como um todo ao desenvolvimento industrial, mas de se investir, sobretudo, na compreensão da ciência envolvida no processo industrial para profissionais capacitados em específico para este ramo.

As fronteiras internacionais não pareciam mais intransponíveis diante da crescente variedade de meios de transporte e comunicação que atingiam os lugares mais remotos. Estradas de ferro, barcos a vapor e linhas de telégrafo intercontinentais suportadas por cabos submarinos se multiplicavam mundo afora, instalados pelos países mais desenvolvidos visando estreitar as relações econômicas entre si com custos reduzidos e maior velocidade. Isso não impactou somente as relações comerciais, como também ampliou os horizontes geográficos do europeu comum, cada vez mais ávido em consumir literatura de viagem, desenvolvida a partir dos relatos de naturalistas viajantes que exploravam a Ásia, África, Austrália, América do Sul e Central. A velocidade da difusão de informações sobre o Novo Mundo era bastante pequena para sair de seu local de origem, podendo levar de oito a nove meses, mas assim que chegava nas metrópoles, sua divulgação para outras partes do mundo se dava em questão de horas através das redes telegráficas.

A inserção do Brasil neste conjunto de transformações internacionais ganhou novos contornos desde o estabelecimento da família real portuguesa na então colônia americana de Portugal no ano de 1808, elevada à categoria de Reino Unido de Portugal, Brasil e Algarves em 1815. As invasões napoleônicas a Portugal, que haviam motivado a transferência da família real ao Brasil, devastaram o comércio local, sustentado especialmente pela matéria-prima brasileira, o que abriu margem para a intensificação das relações comerciais brasileiras com a Inglaterra. Além disso, Portugal estava sob protetorado inglês após a derrota das tropas de Napoleão com auxílio da Inglaterra, enquanto a sede administrativa do reinado de D. Maria I permanecia no Rio de Janeiro. Tal situação foi crítica para a burguesia comercial portuguesa e se tornou motivação principal para a Revolução Liberal do Porto em 1820, que exigiu a restauração da exclusividade do comércio entre Brasil e Portugal estabelecida pelo Pacto Colonial e o retorno imediato da Corte para a Europa, o que aconteceu em 1821, permanecendo D. Pedro de Alcântara no 
Brasil na condição de Príncipe Regente até a independência em 1822, quando se tornou Imperador. Com isso, a monarquia absolutista portuguesa cedeu espaço para uma monarquia liberal apoiada pela burguesia, modelo político que o Brasil adotaria a partir da independência.

Embora a inserção brasileira no sistema capitalista oitocentista fosse bem delineada por suas relações comerciais com Portugal e Inglaterra, um elemento de "estranheza" ainda permeava as representações europeias sobre o país. Fosse por seu clima tropical; fosse por sua população que mesclava elementos étnicos negros, brancos e indígenas; fosse por sua fauna e flora locais tão diferentes do Velho Continente ou pelos recursos naturais que poderiam servir de matéria-prima ao comércio e à indústria, o Brasil era tido como um lugar exótico, que inspirava relatos curiosos de europeus de passagem pelo país. Os relatos impressos sobre o Novo Mundo, repletos de exotismo e elementos pitorescos, levavam à população europeia retratos subjetivos de paisagens, pessoas, viagens e espécimes de animais e plantas nativos. Tanto os relatos de naturalistas viajantes, motivados por interesses científicos, quanto os de curiosos interessados que acompanhavam expedições científicas ou viajavam por conta própria pelo prazer da aventura continham ricos detalhes dos locais visitados, mesclados com impressões pessoais sobre fatos vividos, pessoas encontradas e paisagens observadas, de tal modo que, ainda não estabelecido um padrão de linguagem e escrita científica como ocorreria no final do século XIX, pouco se distinguia entre as observações de um cientista e as de um literato. Na segunda metade desse século, o empreendimento das expedições científicas em grupos numerosos, compostos por naturalistas experientes, estudantes universitários e diletantes em geral, ganhava maior espaço em relação às viagens solitárias dos naturalistas anteriores, conferindo à formação de novos naturalistas uma vivência até então pouco trabalhada nas instituições europeias e norte-americanas que ofereciam tal opção profissional. Neste sentido, "naturalistas de gabinete", cujos estudos se restringiam à análise de espécimes coletadas e disponibilizadas em museus de história natural, iam-se tornando obsoletos no contexto de um mundo cada vez mais interligado sob a égide do capitalismo. Os diários de viagem sobre as paisagens brasileiras e seus componentes de fauna e flora traziam notas precisas e até ilustrações sobre espécimes coletados e observados, permeadas com comentários sobre a exuberância das florestas e rios, a vasta diversidade de animais e plantas, os estranhos - aos olhos europeus - costumes das populações locais urbanas e dos interiores, imagens que refletiam o imaginário europeu sobre o Novo Mundo e a ele traziam novos elementos, como o nível de urbanidade atingido por Belém, comparável a uma metrópole europeia em menor escala, no curto espaço de tempo em que Henry Bates visitou a cidade pela primeira vez ao iniciar sua expedição e seu retorno à Inglaterra dez anos depois. Nas palavras do naturalista:

Achei o Pará muito modificado e melhorado. Não era mais aquele lugar com aspectos de aldeia cheia de mato, ameaçando ruína, que eu vira quando a conheci em 1848 (...). A população aumentara (...) pela imigração de portugueses, madeirenses e alemães, e durante muitos anos o considerável saldo de orçamento tinha sido gasto pelo governo em embelezar a cidade. (BATES, 1979, pp. 392-93).

Esta visão sobre a capital da província do Grão-Pará apresentava uma região dividida entre o exotismo que contemplava o olhar europeu sobre o Novo Mundo e a integração com o "mundo civilizado", pela importação de referenciais europeus e norteamericanos para a arquitetura, vestuário, costumes, gostos e lazeres das elites locais. Isso ficaria sobretudo evidente na transição entre os séculos XIX e XX, na denominada belle 
époque amazônica, cujos maiores expoentes foram Belém e Manaus (DAOU, 2004). As duas maiores concentrações urbanas da província passaram por transformações estéticas e culturais que refletiam o espírito cosmopolita que se buscava construir no país, criando em seus cidadãos um sentido de pertencimento e íntima relação com as civilizações europeias, apesar das distâncias oceânicas que separavam o Velho Continente e a região amazônica. De fato, o depoimento de Alfred Wallace em sua passagem pela Amazônia denota alguma similitude entre a paisagem urbana local e o cotidiano europeu:

Minhas anteriores excursões limitaram-se a passeios pela Inglaterra e a uma curta viagem pelo Continente, de modo que tudo por aqui tinha para mim o encanto de uma completa novidade. No todo, entretanto, eu estava desapontado. O tempo não era tão quente, as pessoas não eram tão diferentes, a vegetação não era tão extraordinária, nada coincidia com a fantástica imagem que eu formara em minha imaginação e que ardentemente acalentara durante o tédio de uma travessia marítima. (...) (WALLACE, 1979, p. 18).

A decepção do naturalista por não encontrar o ambiente exótico que criara em sua imaginação durante a viagem ao Brasil exprime uma familiaridade com o espaço urbano de Belém, compreensível pela adoção dos modelos padrões de organização urbana comuns às cidades europeias. Neste sentido, a contradição entre o familiar e o exótico marcada pela perspectiva do viajante é um elemento crucial na constituição da identidade amazônica, calcada em última instância pelas relações econômicas pelas quais se configurava sua integração na totalidade do mundo daquela época.

Entretanto, traços desta inserção do Brasil na moderna organização mundial chancelada pela burguesia já se faziam presentes durante o período da Conciliação (18401851), quando se buscava reunir as diversas regiões brasileiras sob a imagem de liderança do jovem imperador D. Pedro II.A inserção do Brasil no "mundo civilizado" era uma ideia concebida naquilo que Ilmar Rohloff de Mattos (1987) denomina de jogo de semelhanças e diferenças entre o Império brasileiro e as nações industrializadas. Buscava-se incutir nos homens livres do Império uma identidade que os fizesse se reconhecerem como parte da civilização ocidental, através do progresso material e espiritual que se operava naqueles tempos, na visão de analistas da época. O período da Conciliação na década de 1850 proporcionou percepções mais otimistas acerca desta identificação, não somente pela estabilidade política que caracteriza este momento histórico, bem como pelos avanços nos meios de transporte fluvial e férreo e nas comunicações telegráficas, pelas operações militares bem-sucedidas na província Cisplatina e pela extinção do tráfico negreiro internacional. Este otimismo se refletia no sucesso comercial internacional de fontes econômicas até então secundárias, como é o caso da borracha amazônica.

Desde a Independência do Brasil, a economia na província do Grão-Pará se reforçava pela extração e exportação da borracha. $O$ produto da seringueira já era comercializado em pequena escala desde o início do século XIX, mas se tornou eixo da economia amazônica a partir de 1840 , quando o processo de vulcanização descoberto por Charles Goodyear no ano anterior possibilitou maior durabilidade e maleabilidade dos produtos confeccionados a partir do látex. Com isso, além do látex virgem, calçados, mochilas e outros artefatos foram exportados diretamente do Pará para a Europa e para os Estados Unidos em larga escala, tornando-se em 1870 a principal fonte de renda da província (SARGES, 2000). Entre 1870 e 1910, a economia amazônica passou por um vigoroso surto sustentado pelo comércio internacional do látex, especialmente quando se 
tornou possível contornar alguns dos principais obstáculos à produção. A mão-de-obra para extração da borracha, por exemplo, era considerada escassa, motivando os governos provinciais a incentivar a imigração interna, com o estabelecimento de colônias constituídas mormente por nordestinos que escapavam da seca, da grande mortandade do rebanho pecuarista e da decadência das indústrias do açúcar e do algodão. Embora a produção da borracha tenha se expandido consideravelmente com os incentivos à imigração nordestina, a base da cadeia produtiva permanecia centrada no seringueiro, explorado através do sistema de aviamento. O seringueiro estaria preso ao extrativismo pois acumulava dívidas com as casas aviadoras, que lhe forneciam desde os utensílios básicos para a extração do látex até a alimentação que o sustentaria enquanto não aprendesse a caçar. Frequentemente as dívidas dos seringueiros com as casas aviadoras eram abusivas, de modo que toda a produção obtida nos seringais era destinada à casa $\mathrm{e}$ ainda era insuficiente para livrar o seringueiro do débito adquirido. Com base neste sistema, Sarges (idem) afirma que a economia gomífera acabou com as estruturas escravagistas na Amazônia e a integrou aos mecanismos de poder do capitalismo internacional.

Assentado sob a exploração do trabalho do seringueiro, o desenvolvimento econômico das elites locais era notório, repercutindo na aquisição de novos hábitos, pensamentos e modelos inspirados na Europa, mais precisamente em Paris. A arquitetura de Belém e Manaus foram consideravelmente modificada para corresponderem às influências parisienses, com fortes marcas do art nouveau e uso do ferro como matériaprima preferencial. Construções como o Mercado de Ferro da feira do Ver-o-Peso, a loja de tecidos Paris n'America, o Theatro da Paz em Belém e o Theatro Amazonas em Manaus foram erguidas no contexto dessa belle époque proporcionada pela ascensão da borracha como principal produto de exportação da Amazônia. Embora tais obras buscassem atender aos anseios das elites locais, as camadas pobres da cidade foram preteridas destes benefícios, pois os cortiços que existiam no centro da cidade foram destruídos e as famílias despejadas, sendo obrigadas a se mudar para as periferias, onde o desenvolvimento urbano impulsionado pela exportação da borracha foi praticamente nulo (SARGES, idem).

Ao assumirmos a plena inserção da Amazônia oitocentista na fase contemporânea do capitalismo internacional e que a adoção de modelos, tendências e ideias oriundos de países capitalistas mais avançados é consequência desta inserção, o pensamento liberal, reflexo da vitória política da burguesia em países como França, Inglaterra, Alemanha e Estados Unidos, seria também compartilhado entre as regiões inseridas, ainda que de forma dialética às condições locais, buscando superar as contradições decorrentes da tensão entre universal e local. Assim, os ideais liberais que apoiavam o desenvolvimento das sociedades capitalistas chegaram ao Brasil e adquiriram sentidos semelhantes aos adotados nos demais países, orientando discursos e ações dos homens públicos e demais defensores do liberalismo. No país, a recepção dos ideais liberais tinha como via fundamental a formação universitária dos políticos que assumiam as cadeiras da Assembleia Nacional, em especial médicos e bacharéis em direito formados no Brasil e em Portugal. A formação e fortalecimento do Partido Liberal brasileiro foi um marco na consolidação daqueles ideais na agenda administrativa oficial, de modo que se falava em liberdade, progresso, civilização e democracia como valores essenciais a toda e qualquer sociedade avançada, apesar de serem contraditos no país pela manutenção da escravidão e do regime monarquista de governo. Era comum que os discursos oficiais aludissem a urgência de se tratar determinados temas, como saúde e instrução pública, em nome do progresso do país e da civilização do povo. 
A classe política brasileira prezava aqueles valores, invocados nos discursos dos mais diversos políticos. A geração de políticos atuantes a partir da Conciliação era composta por representantes da oligarquia rural e um crescente número de representantes dos núcleos urbanos, em grande parte membros de famílias latifundiárias afastados destas atividades e formados em faculdades brasileiras ou portuguesas. Embora em um primeiro momento a identificação dos políticos rurais com o Partido Conservador e dos urbanos com o Partido Liberal seja cabível, esta não seria a realidade nos anos que se seguiram à posse de D. Pedro II. Emília Viotti da Costa (2008) demonstra que uma das frases mais comuns da política imperial no Segundo Reinado era "não há nada mais parecido com um liberal que um conservador". Isso indica que, apesar das divergências ideológicas em alguns aspectos, os projetos de liberais e conservadores para a sociedade brasileira visavam atender aos interesses dos mesmos grupos. Os poucos liberais que assumiam posturas mais radicais e os poucos conservadores que se mostravam irredutíveis a qualquer concessão iriam desaparecer do cenário político com o tempo. Neste sentido, as ações dos membros de ambos os partidos nas províncias brasileiras e no Município Neutro, onde era sediado o Império, consistiam em reformas legislativas com alterações e adaptações adequadas ao contexto político e social vigente.Os fundamentos do pensamento liberal, instituído pela vitória da burguesia na Revolução Francesa de 1789, remetem, grosso modo, aos princípios de representatividade política igualitária; de acesso universal à educação pública, laica e gratuita; de liberdade do pensamento e de religião; de defesa da propriedade privada, da livre economia e da mínima intervenção do Estado. Estes princípios foram enfatizados por políticos, intelectuais, literatos e jornalistas brasileiros, mais ou menos próximos ao Partido Liberal, uma vez que a denominação do partido, conforme Costa (2008), não impedia que seus quadros contassem com indivíduos mais identificados com posturas conservadoras, assim como existiam membros do Partido Conservador mais alinhados aos princípios liberais. Com isso, a simples identificação partidária de um ou outro sujeito pesquisado é insuficiente, quando não enganosa, para compreender seu posicionamento ideológico.

Sérgio Adorno (1988) aponta quatro movimentos responsáveis pela introdução, difusão e absorção cultural do ideário liberal no Brasil pré-independência: formação dos intelectuais brasileiros em na Universidade de Coimbra, em Portugal; participação das sociedades secretas no movimento emancipatório; envolvimento dos clérigos com a maçonaria e proliferação dos movimentos separatistas. Embora o liberalismo em si não tenha causado a emancipação brasileira da condição de colônia, foi o elemento ideológico alternativo ao colonialismo, apesar de suas contradições inerentes e seus conflitos com situações concretas que permaneceram no período imperial acerca das diferenças sociais, estruturas de poder e manutenção do sistema escravista. Em consequência disso, a inserção das "fórmulas universalizantes e abstratas" do pensamento liberal no Brasil não foi recebida sem conflitos de classe, que culminaram em lutas armadas no período regencial, dado o distanciamento entre as propostas liberais e os anseios das classes populares oprimidas pelas estruturas de poder, que não percebiam qualquer benefício real com a emancipação política do país. Em outras palavras, a luta pela liberdade das camadas populares equivalia à luta por igualdade, ao passo que a defesa da liberdade pelos liberais representantes do poder político e social dominante excluía deliberadamente o sentido de igualdade para resguardar o patrimônio e os privilégios adquiridos de seus membros (ADORNO, idem).

Neste contexto, a criação de uma intelligentsia brasileira no século XIX está diretamente associada à figura do bacharel formado nas Academias de Direito do país e de 
Portugal. $\mathrm{O}$ acesso facilitado dos bacharéis às estruturas administrativas do Império possibilitou "a formação de uma consciência nacionalista, fundada em bases ético-jurídicas e que encontrou nas teses liberais seu ponto de convergência" (ADORNO, 1988, p. 78), de modo que os cargos dos poderes executivo, legislativo e judiciário foram ocupados predominantemente por bacharéis. $\mathrm{O}$ intelectual formado neste âmbito tinha no jornalismo seu principal instrumento de luta, onde disseminavam saberes não somente sobre temas jurídicos, como também sobre questões de interesse nacional. Era, segundo Adorno (idem), um intelectual política e moralmente educado e disciplinado, segundo as teses e princípios liberais, responsável pela coesão entre as elites políticas e os interesses dominantes ao ocupar espaços estratégicos para a articulação entre poder de Estado e ordem social. A criação de cursos jurídicos no Brasil, iniciada pela Faculdade de Direito do Largo de São Francisco (São Paulo) em 1827, se constituiu como um celeiro de difusão dos ideais liberais e formação de "políticos profissionais" sob estes ideais.

Após uma breve apresentação dos elementos acima que possibilitam contextualizar o período em questão, passamos à análise da legislação educacional paraense, objetivo principal deste estudo.

\section{Legislação educacional paraense: entre discursos e práticas}

A instrução pública proposta pela legislação provincial a partir da criação da Diretoria de Instrução Pública em 1841 seguia a tendência de adotar as indicações da Corte para o ensino secundário, ao passo que os métodos e o conteúdo do ensino primário seriam responsabilidade de cada província, como preconizava o Ato Adicional de 1834. Isto posto, a regulamentação da instrução pública instituída pela Lei $\mathrm{n}^{\circ} .97$ de 28 de junho de 1841, sancionada pelo Vice-Presidente da província Bernardo de Souza Franco em 3 de julho do mesmo ano, descreve a composição das classes de estudos para a instrução primária e dos cursos de Humanidades e Comércio para a instrução secundária. Trata-se da primeira iniciativa formal na província do Grão-Pará de regulamentar a instrução pública, com a criação de uma Diretoria de Instrução Pública como órgão próprio para fiscalizar e inspecionar escolas e classes, função inexistente até então.

As classes seriam compostas das seguintes matérias: a primeira, por "Leitura e Escrita ou Caligrafia, Princípios de Aritmética com o perfeito conhecimento das quatro operações aritméticas em números inteiros, fracionados, complexos e proporções; Gramática da Língua Nacional, e elementos de Ortografia". A segunda continha "Princípios de Moral Cristã e da Religião do Estado, Noções de Civilidade, Elementos Gerais de Geografia, Leitura da Constituição e da História do Brasil". Para as aulas para o sexo feminino, seriam inclusos "o uso da agulha de cozer, e de meia; o bordado, as regras de talhar e cozer os vestidos, e os mais misteres próprios da educação doméstica". Note-se a grande semelhança entre as matérias do ensino primário propostas pela lei provincial e a Lei das Escolas de Primeiras Letras de 1827, indicando uma possível influência desta sobre aquela.

O artigo $4^{\circ}$ estabelece como método de ensino da instrução primária aquele desenvolvido pelo Barão de Gérando, voltado para a formação de professores primários para a aplicação do ensino mútuo nas escolas. O livro Curso Normal para Professores de Primeiras Letras ou direções relativas a Educação Physica, Moral e Intelectual nas Escolas Primárias, publicado originalmente em francês no ano de 1832 pelo referido Barão, tem sua primeira tradução para o português em 1839 e desde então era considerada 
obra de referência pelos governos de diversas províncias brasileiras para orientação aos professores do ensino primário acerca dos princípios do ensino mútuo. Todavia, essencialmente os objetivos do curso eram moralizantes em detrimento dos aspectos teórico-metodológicos, pois visava a formação de cidadãos dóceis e submetidos à ordem (BASTOS, 1998).

Para a instrução secundária, como determina o capítulo segundo da Lei, planejou-se a oferta de um curso de Humanidade e um curso de Comércio a serem ofertados em Liceus. Cada Liceu disporia de cadeiras de: " $1^{a}$ Língua Latina; $2^{a}$ Língua Francesa; $3^{a}$ Aritmética, Álgebra e Geometria; $4^{\mathrm{a}}$ Filosofia Racional e Moral; $5^{\mathrm{a}}$ História Universal, Geografia Antiga e Moderna, História do Brasil; $6^{\mathrm{a}}$ Retórica, Crítica, Gramática Universal e Poética; $7^{\mathrm{a}}$ Escrituração Mercantil e Contabilidade; $8^{\mathrm{a}}$ Língua Inglesa". O artigo $10^{\circ}$ determinava que as sete primeiras cadeiras comporiam o curso de Humanidade, com duração de cinco anos, e que as cadeiras correspondentes aos ordinais $2^{\mathrm{a}}, 3^{\mathrm{a}}, 4^{\mathrm{a}}, 5^{\mathrm{a}}, 7^{\mathrm{a}}$ e $8^{\mathrm{a}}$ formariam o curso de Comércio, com duração de dois anos. Foi determinado no artigo seguinte a criação de um único Liceu com sede na capital, a ser denominado de Liceu Paraense, além da previsão de uma aula de Ensino Normal também na capital (artigo 13). As cadeiras de Latim já existentes em Cametá, Macapá e Santarém foram mantidas, e uma foi criada na Vila de Bragança.

A Lei $n^{\circ} .203$ de 27 de outubro de 1851, que se seguiu à anterior, foi sancionada pelo presidente Fausto Augusto D'Aguiar, regulamenta a instrução pública com mais detalhes que a Lei de 1841, trazendo modificações sensíveis em relação a ela. A primeira parte, "Da instrução primária", inicia definindo o objeto do ensino primário, ao separar em seu artigo $1^{\circ}$ as escolas de instrução primária em primeiro e segundo graus. Nas escolas de primeiro grau, o aluno é ensinado a ler, escrever, fazer operações aritméticas até proporções, gramática e ortografia prática e noções dos deveres morais e religiosos. Nas escolas de segundo grau, o aluno aprende a ler, escrever, fazer operações aritméticas aplicadas ao comércio, geometria prática, gramática nacional, noções gerais de história e geografia do Império, noções dos deveres morais e religiosos, leitura da Constituição e do Código Penal do Império.A criação de novas escolas para meninas pelo governo provincial estaria condicionada à demanda de pelo menos 20 alunas, sendo que as escolas que não atingissem a frequência mínima designada durante um ano seriam extintas ( $\operatorname{art} .5^{\circ}$ ). Quanto ao ensino, todas as escolas primárias para o sexo feminino deveriam seguir o método simultâneo, constando as matérias de ler, escrever, gramática e ortografia prática, aritmética até as quatro operações, noções dos deveres morais e religiosos e "os misteres próprios à educação do sexo" (art. $\left.6^{\circ}\right)$.

No dia 8 de novembro do mesmo ano de 1851, o presidente Fausto Augusto D'Aguiar elaborou um regulamento para o Liceu Paraense, amparado pelo artigo 36 da Lei $\mathrm{n}^{\circ}$. 207 que o autorizava este expediente. Com isso, definiu no capítulo $1^{\circ}$, referente ao programa de estudos e à ordem de ensino, que seriam ensinadas matérias em 6 anos, cujas cadeiras se dividiram em:
$\S 1^{\circ}$. Latim.
$\S 2^{\circ}$. Língua Francesa.
$\S 3^{\circ}$. Língua Inglesa.
$\S 4^{\circ}$. Aritmética, Álgebra, Geometria plana e no espaço, Trigonometria retilínea, Escrituração mercantil.
$\S 5^{\circ}$. História universal e Geografia, especialmente do Brasil.
$\S 6^{\circ}$. Filosofia racional e moral. 
$\S 7^{\circ}$. Retórica e poética.

$\S 8^{\circ}$. Elementos de física e de química, e princípios gerais de Botânica.

$\S 9^{\circ}$. Desenho geométrico e topográfico, com conhecimento das ordens da Arquitetura. (REGULAMENTO PARA O LICEU PARAENSE, art. $\left.1^{\circ}, 1851\right)$.

A ordem do ensino foi definida no artigo $2^{\circ}$ do seguinte modo: no primeiro ano de curso, seriam ensinados Latim, Francês, Aritmética e Álgebra; no segundo ano, Latim, Francês Geometria, Trigonometria, Escrituração mercantil e Inglês; no terceiro ano, Latim, Inglês e História e Geografia; no quarto ano Latim, História e Geografia, Filosofia e Retórica; no quinto ano, Filosofia e Retórica, Elementos de Física e Desenho; no sexto e último ano de curso, Desenho, elementos de Química e princípios gerais de Botânica. No entanto, as duas últimas cadeiras foram extintas no ano seguinte por não haver professores habilitados para assumi-las, de acordo com o próprio presidente Fausto D’Aguiar.

Alguns anos mais tarde, em 6 de dezembro de 1859, a Lei $\mathrm{n}^{\circ} 348$, decretada pelo presidente Antonio Coelho de Sá e Albuquerque autorizava o governo da província a reformar a instrução pública, tendo por princípios a supressão das escolas de instrução primária conforme o conveniente; a divisão das cadeiras existentes de História e Geografia e Aritmética, Álgebra e Geometria em quatro cadeiras: História Universal, em particular a do Brasil; Geografia; Aritmética, Álgebra e Geometria e Contabilidade e Escrituração Mercantil e a reforma dos professores vitalícios que não puderem mais continuar no magistério, mesmo que não tenham completado o mínimo de dez anos previsto em lei para isso. As cadeiras criadas por esta lei poderiam ser preenchidas pelos professores do Liceu que tivessem habilitações para rege-las, recebendo anualmente 600 mil-réis correspondentes a cada uma delas. Além disso, a supressão de escolas de instrução primária poderia implicar no aumento dos ordenados dos respectivos professores, nos limites da verba voltada para tal. As propostas presentes nesta lei seriam ainda submetidas à aprovação da Assembleia Provincial em sua próxima reunião, o que ocorreu em 20 de dezembro daquele ano.

A implantação desta reforma foi discutida na Assembleia Legislativa Provincial no mês anterior, com intenso debate entre os deputados, conforme registrado na transcrição da sessão de 19 de novembro de 1859 publicada nas edições dos dias 7 e 9 de janeiro de 1860 do jornal Diario do Gram-Pará. Um projeto de reforma da instrução pública apresentado na Assembleia pelos deputados Costa Pimentel, Antonio Gentil Augusto e Silva e Manoel Antonio Rodrigues estava em discussão, o que suscitou diversos apartes dos deputados presentes acerca da necessidade apresentada pelo deputado Joaquim Correa de Freitas de conhecer o número de cadeiras interinas na instrução primária, cuja supressão era autorizada pelo projeto. $\mathrm{O}$ aparte mais longo foi proferido pelo deputado Gama Abreu, ao comparar o projeto em discussão com outros dois projetos apresentados anteriormente na Casa, dizendo-se "admirado" e "pasmo" uma vez que este projeto seria uma fusão dos projetos anteriores, considerados inconciliáveis entre si. Após alguns argumentos de outros deputados acerca da viabilidade do projeto em debate, Abreu afirmava ser necessário colher mais informações sobre o estado da instrução antes de votar sobre a reforma, insistindo na impossibilidade de execução do projeto tal qual se apresentava, o que foi desaprovado por vários dos presentes. Em resposta, Abreu toma a palavra e se pronuncia:

Reforme-se o que se quiser, façam as reformas que se pedem em qualquer dos ramos, ou no pessoal; ou na parte que diz respeito ao ensino das matérias, nem assim obteremos reformar a instrução primária; e repito 
isto porque eu vejo que a assembleia da província do Pará não quer tratar da matéria de instrução pública (...) Eu desejava, senhores, que a assembleia não desse este passo, mas é forçoso que o dê; é forçoso que faça o seu ato de contrição; é forçoso que siga, já que chegamos a este ponto; já que temos descido tão baixo e que não somos capazes de obter uma medida profícua a bem da província; já que não sabemos fazer calar os sentimentos particulares de cada um de nós; já que não apresentamos uma lei que seja capaz de trazer instrução ao povo; já que queremos deixar ficar as escolas no estado em que estão; já que não sabemos, não queremos ou não podemos fazer nada em benefício da instrução pública; já que conhecemos tudo isto e não temos força para calar o espírito de proteção que domina a assembleia, que é o motor de muitas ações que tem praticado e que eu não calo e hei de repetir sempre; já que não queremos reconhecer tudo isto, e ao mesmo tempo emendar a mão, dando medidas profícuas, tratando do bem público, e deixando as questões particulares; já que não acreditamos em nada disto; já que estamos sempre falando em dinheiro, não sabendo que o professor é que dá instrução ao povo, que são os homens que mais tratam da educação dos nossos filhos; já que estamos sempre marchando como se a província não tivesse recursos; não querendo reconhecer que ela sua ouro por todos os seus poros, que tem dinheiro para pagar aos seus funcionários que a administram bem; já que queremos deixar de parte a riqueza; já que não convém reconhecer isto, reconheçamos ao menos que com aquele projeto se autoriza o homem que, por enquanto, está fora de nossas dissensões políticas, e que pode assim fazer algum bem sobre este ramo da instrução pública, como de outros muitos, adotemos aquele projeto, depositemos as nossas esperanças nas mãos de um homem que não está por ora eivado das nossas dissensões políticas. (DIÁRIO DO GRAM-PARÁ, 9 de janeiro de 1860, p. 1).

A fala do deputado Gama Abreu, descontado seu apelo demagógico, é oportuna a respeito da importância atribuída à instrução pública no plano do discurso formal, em contradição à pouca efetividade das práticas adotadas na província. $\mathrm{O}$ projeto de reforma estava, como tantos outros projetos elaborados e discutidos na Assembleia Legislativa Provincial, à mercê das disputas partidárias entre liberais e conservadores, tornando a sessão palco de interesses negociados de acordo com as aspirações de cada partidário. Para buscar superar o partidarismo das discussões, Abreu sugere que a Assembleia autorize o presidente Sá e Albuquerque a executar a reforma da instrução conforme sua perspectiva, uma vez que se trata de "um homem que não está por ora eivado das nossas dissensões políticas" (idem). Embora esta reforma tenha sido aprovada em dezembro de 1859, outra proposta seria apresentada e aprovada no ano seguinte.

Sancionada em 31 de outubro de 1870, a Lei $\mathrm{n}^{\circ}$. 664 propunha reformas na instrução primária, subdividindo-a em ensino primário inferior e ensino primário superior. Enquanto aquele seria composto por leitura, escrita, operações fundamentais sobre números inteiros e fracionários, noções práticas do sistema métrico de pesos e medidas, noções de gramática portuguesa e moral civil e religiosa ( $\operatorname{art.} 1^{\circ}, \S 1^{\circ}$ ), este seria composto por gramática portuguesa, elementos de aritmética e geometria, geografia, história e noções rudimentares de ciências físicas e naturais (art. $1^{\mathrm{o}}, \S 2^{\circ}$ ). Toda paróquia da província deveria ter uma escola de ensino primário inferior do sexo masculino; na capital, haveria duas escolas do ensino primário superior e nas cidades cujas escolas fossem frequentadas 
por mais de 150 alunos haveria mais uma escola de ensino primário inferior e uma do superior $\left(\operatorname{art.} 2^{\circ}\right)$. $\mathrm{O}$ ensino primário inferior seria obrigatório $\left(\operatorname{art.~} 3^{\circ}\right.$ ), e as escolas que funcionassem em vilas e freguesias cuja frequência fosse inferior a 60 alunos seriam regidas pelos párocos ou pessoas idôneas a receberem gratificação de 500 mil-réis, com o aluguel das casas onde funcionassem as escolas sendo custeado pelo tesouro provincial $\left(\right.$ art. $\left.4^{\circ}\right)$. Escolas para o sexo feminino seriam também criadas nas localidades onde a frequência habitual das meninas fosse superior a vinte alunas (art. $7^{\circ}$ ), e seu ensino compreendia a leitura, escritas, as quatro operações sobre números inteiros, gramática portuguesa, moral civil e religiosa e costura. As professoras das escolas para o sexo feminino receberiam o mesmo ordenado dos professores do ensino primário inferior, mais um acréscimo de 100 mil (na capital) ou 50 mil (outros locais) para aluguel das escolas. Os exames para contratação de professores via concurso, para o provimento de escolas que não correspondessem ao artigo $4^{\circ}$, seriam feitos diante da congregação de lentes do Liceu (não mais Colégio Paraense), que arguiriam livremente o candidato dentro das matérias que tivesse que ensinar, sendo que somente o candidato que fosse plenamente aprovado obteria provimento efetivo $\left(\operatorname{art} .10^{\circ}, \S 4^{\circ}\right)$.

Antes desta lei ser aprovada, seu projeto foi alvo de uma série de críticas tecidas em uma série de artigos no jornal $O$ Liberal do Pará entre 16 e 22 de outubro de 1870 pelo exdiretor de instrução pública, dr. Américo Santa Rosa. Através deles, o autor dizia exercer "o dever de demonstrar que a reforma projetada, bem longe de concorrer para o melhoramento da instrução, irá acanhar o desenvolvimento da inteligência dos meninos, e deixar nas trevas da ignorância as populações do interior" (O LIBERAL DO PARÁ, 16 de outubro de 1870, p. 1). Primeiramente, a divisão do ensino primário em superior e inferior é considerada útil e conveniente, mas que somente teria efeito caso cada localidade possuísse uma escola de cada nível. Entretanto, de acordo com as determinações do regulamento, somente nas localidades com mais de 150 alunos haveria escolas superiores, o que comprometeria o acesso das crianças e jovens do interior ao ensino primário completo. Também se critica as matérias que compõem a proposta da reforma, uma vez que, em comparação com o regulamento em vigor, aprovado em 1864, o sistema métrico não seria ensinado e a aritmética e a gramática seriam reduzidas a noções. Santa Rosa atribui estas mudanças a um projeto deliberado de reduzir a qualidade do ensino popular, por um suposto medo que houvesse de que a população pudesse questionar o governo pelo acesso ampliado à instrução. Esta ideia é ilustrada da seguinte forma:

Não podemos julgar o ilustrado autor do projeto sectário das ideias de certos espíritos tacanhos, que olham assombrados para o desenvolvimento intelectual do povo e proclamam ufanos o célebre paradoxo do Rei de Nápoles: o meu povo não precisa pensar, porque o meu governo se encarrega de pensar por ele. (...) Como disse um dos nossos ex-ministros: "O Brasil não pode ser, nem é indiferente a este movimento civilizador do século XIX. Do melhoramento da instrução pública depende essencialmente o desenvolvimento pacífico de suas instituições livres, a conservação de sua integridade, a grandeza de seu futuro, o complemento dos seus altos destinos" (O LIBERAL DO PARÁ, 16 de outubro de 1870, p. 1).

Na edição do dia 18 de outubro, Santa Rosa anuncia que a partir daquele número discutirá sobre os problemas no projeto da reforma da instrução pública em contraposição aos artigos em sua defesa assinados pelo diretor interino da instrução pública, dr. José Felix Soares, no jornal Diario de Belem, considerando-se em desvantagem em relação ao 
debatedor por sua reconhecida ilustração e conhecimento do tema. Continua então a analisar o projeto ao comparar a posição de Soares acerca dos benefícios da reforma com a de que ela na verdade representaria um retrocesso e contribuiria para o embrutecimento paulatino da população. Seu principal argumento nesta edição diz respeito à possível diminuição no número de escolas o interior que o projeto apresenta, o que era contraditório à "opinião de autoridades respeitáveis do nosso país e do exemplo dos países estrangeiros, que mostram a conveniência da disseminação das escolas" (O LIBERAL DO PARÁ, 18 de outubro de 1870, p. 1). Utiliza-se inicialmente de uma fala do conselheiro José Liberato, para quem "levar a instrução primária a todos os pontos do território é o desiderato, a condição de progresso, de prosperidade e de grandeza nacional; a este respeito muito pouco têm feito as Assembleias Provinciais" (idem). Outra opinião é emprestada do senador Leitão da Cunha, quando foi diretor da instrução pública em 1853:

(...) o que é necessário é cuidar seriamente na educação do povo, aumentando-se os meios de prestar-lho, embora seja de mister grande aumento de despesa e mesmo cópia de sacrifícios; porque a primeira e mais palpitante necessidade de um povo livre é a educação...

Lancemos os olhos para o estrangeiro, e vejamos como os povos civilizados têm compreendido a necessidade da multiplicação das escolas (...) (idem).

Santa Rosa reafirma a importância do investimento governamental na instrução pública independentemente dos custos que representa, levantada pelo deputado Gama Abreu em 1859, com base na justificativa de seu papel essencial para a civilização dos povos. Mais uma vez, o sentido civilizador da instrução é evocado como prioridade ideal das ações do Estado, sempre em contraposição às poucas ações efetivamente tomadas para o emissor do discurso.Na edição de 22 de outubro, analisa-se o projeto já depois de aprovado e à espera da sanção presidencial. Diante da inevitabilidade da efetivação da lei, que não apresentou maiores alterações em relação ao projeto, Santa Rosa sugere a criação de associações para o desenvolvimento da instrução primária que se responsabilizassem em criar escolas a partir da iniciativa privada para suprir as carências das localidades onde elas fossem extintas. A manutenção das escolas estaria por conta de comissários eleitos pelas próprias associações, em substituição ao papel dos delegados de instrução pública governamentais, que estariam em seus cargos por mera conveniência política. Sintetiza sua ideia nos termos seguintes: "Fundam-se associações filantrópicas para os órfãos, para os doentes pobres, para a emancipação do elemento servil, por que não as poderemos fundar do mesmo modo para o derramamento da instrução popular?" (O LIBERAL DO PARÁ, 22 de outubro de 1870, p. 1).

As reformas da instrução propostas e executadas tinham por pano de fundo a fundamental relevância com que esta deveria ser tratada para o bem da província e de sua população, bem como para o desenvolvimento de uma nação culta e civilizada. Este posicionamento se coaduna com o tratamento conferido à instrução pública nos discursos oficiais e nas propostas para sua reforma, como no conhecido exemplo dos pareceres do jurista e deputado Rui Barbosa acerca da proposta para a reforma da instrução pública no Município Neutro de autoria do ministro Leôncio de Carvalho. A tese de Maria Cristina Gomes Machado (2002) analisa os pareceres sob o prisma da compreensão de Rui Barbosa acerca da importância da modernização do Brasil, através da formação das crianças e jovens para o trabalho industrial. A formação para a indústria seria uma alternativa ao caráter fundamentalmente agrícola da economia brasileira, de modo que Rui Barbosa considera fundamental a inclusão de disciplinas científicas, ginástica e desenho como parte 
do conteúdo a ser ministrado no ensino secundário. Para o ensino primário, o método intuitivo e a lição de coisas seriam bases de introdução ao conhecimento prático e cotidiano, o qual seria plenamente desenvolvido posteriormente na escola e no exercício profissional. Os gastos com a instrução, para o parecerista, não deveriam ser pequenos, dada sua relevância, como se expressa nos dois trechos seguintes:

Sou dos mais rigorosos (...) quando se trata de elevar as despesas públicas; mas não terei pena do que se gastar aproveitadamente com a instrução. É um empréstimo feito ao futuro que será pago com usura; cujos juros crescerão em proporção indefinida. A civilização do país, seja qual for o aspecto sob que a consideremos, tem por principal motor o adiantamento intelectual de todas as classes da população. (BARBOSA, 1942, apud MACHADO, 2002, p. 116)

(...) Não é a terra, nem o numerário o que constitui a riqueza das nações, mas a inteligência do homem; eis a lei fundamental da verdadeira ciência das finanças. Aqui, porém, se a teoria admite, a prática a rejeita. O orçamento do ensino cresce gota a gota: tem direito a milhares de contos, e recusam-lhe centenas de mil réis. Para tudo se contraem empréstimos, e abrem operações de crédito; para a educação do povo nunca! Não se convencem de que a instrução não tem preço. (BARBOSA, 1947, apud MACHADO, 2002, p. 127, nota 12).

Atrelada à preocupação para uma formação profissional, a instrução pública também seria uma ferramenta de constituição da moralidade pública, uma vez que instruiria os estudantes em termos de conduta e comportamento individual. $\mathrm{O}$ combate à "imoralidade" através da educação ganhou maiores dimensões com o predomínio do gabinete conservador na administração do Império, constituindo oficialmente através da legislação educacional o que André Paulo Castanha (s/d) denomina pedagogia da moralidade. Segundo este autor, o funcionamento da escola impelia os indivíduos a assumirem papéis bem delimitados na sociedade imperial, recebendo e reproduzindo valores esperados em relação a sua condição social, caracterizando a centralização e autoritarismo da escola brasileira sob o discurso do bem comum da população. Isto explica a presença constante de matérias relacionadas à educação moral, civilidade e ensino religioso nas reformas da instrução pública analisadas, embora este último tenha sido desobrigado aos não cristãos católicos nas últimas reformas que constituíram as fontes desta pesquisa.

Outro exemplo de debate acerca da instrução pública foi empreendido por Domingos Soares Ferreira Penna, idealizador e primeiro diretor do Museu Paraense. Algumas de suas ideias a respeito da instrução pública se coadunam com o ideário liberal, em especial o que se refere à liberdade de ensino. Essa noção vinha sendo discutida e implementada por reformas, como o Decreto do Ministro do Império Leôncio de Carvalho em 1879, que previa para as escolas brasileiras a desobrigação do ensino religioso aos não católicos, a implantação do sistema de matrículas avulsas e a possibilidade de prestar exames para qualquer disciplina do Colégio sem ter comparecido às aulas. A liberdade de ensino, associada principalmente ao liberalismo dos Estados Unidos, se baseava na noção de democracia republicana, na qual todos teriam o direito de escolha política. Para a instrução, os estudantes teriam o direito de escolher que disciplinas fazer, dependendo de seus objetivos profissionais. 
Um artigo escrito por Ferreira Penna em 1869 para o jornal O Colombo traz algumas ideias do que poderia ser a liberdade de ensino. Penna já se manifestara contra a falta de atenção devida à instrução no interior da província em seu relatório Breve Notícia sobre as Comarcas de Breves e Gurupá, de 1865. Como viria a encontrar situação semelhante nas comarcas de Santarém e Óbidos, reproduziu seu manifesto em A Região Occidental do Pará, de 1867. Em ambos os relatórios, Penna descrevera como os estudantes se acomodavam em escolas com condições precárias, com bancos quebrados, quadro de giz em mau estado, grande evasão escolar e professores com pouca qualificação para educar, embora fossem esforçados. Chegou a chamar os relatórios da Diretoria de Instrução Pública de "ficção oficial", uma vez que traziam somente informações positivas acerca da educação no interior.

No artigo de 1869, Ferreira Penna descrevia como a educação dos jovens no interior estava precária, visto que poderiam no máximo obter a instrução primária, sendo necessário se deslocarem para a capital se quisessem obter a instrução secundária. Outra preocupação do autor era com os livros adotados nas escolas, que divergiam grandemente entre uma escola e outra. Para ele, bastava à instrução primária a adoção de dois livros: $A$ Sciencia do Bom Homem Ricardo, com lições de moral, e qualquer livro de história pátria(PENNA, 1869, p. 2). Além disso, considerava interessante aos jovens do interior ter lições de Hidrografia, Geografia, Geologia, História Natural e Etnografia, para melhor conhecerem sua terra. Em um trecho seguinte do escrito, Penna explicava qual a importância da instrução para o povo, fosse do interior ou da capital:

Como é sabido, não há progresso sem civilização, nem religião verdadeira, nem espírito público onde ao povo falta a instrução que é a base sobre que se apoiam todos os sentimentos nobres do espírito humano. Um povo sem instrução é um rebanho que obedece a vara do pastor que, se o protege contra os lobos, também lhe aproveita a lã e que, quando lhe parece, o conduz ao leilão; mas esse rebanho converte-se também facilmente em lobos para devorar ao pastor a quem sua ignorância atribui a falta de pasto ou a peste que o persegue (PENNA, 1869 , p. 2).

As palavras de Ferreira Penna ecoam o sentido político atribuído pelas elites liberais à instrução popular. A ausência de instrução poderia ser tão ameaçadora quanto sua inserção integral e igualitária, de modo que a população não instruída poderia se tornar facilmente manipulável por agitadores políticos ou se voltar contra lideranças supostamente idôneas ao lhe atribuir culpa pelos males que a atingem. A distância entre a necessidade da instrução pública aos vários segmentos populares e sua oferta efetiva indica a contradição fundamental sobre a qual os discursos acerca da instrução e da educação se sustentam. Assim, por maior importância que se atribua a este tópico nos discursos oficiais, as reformas educacionais implantadas pelos políticos ligados às elites liberais invariavelmente estarão aquém das reais necessidades da população a quem se destinam.

\section{Considerações finais}

O principal objetivo deste artigo foi confrontar a legislação educacional produzida no Pará entre os anos de 1841 e 1870 com discursos nos quais se evidencia a importância da instrução pública como elemento de progresso e civilização de um povo, sustentada como ideia universal e consensual. De fato, tais discursos são marcados pelo ideário liberal predominante entre políticos e intelectuais brasileiros daquele período. Com isso, 
pretendemos demonstrar que a adoção de discursos liberais em relação à defesa da instrução pública repercutiu entre a intelectualidade paraense como reflexo da importância de se conduzir a província a um processo civilizador, no sentido evocado por Norbert Elias (2011) em sua análise da origem deste conceito na Europa. Para o autor, inicialmente indicativa de uma característica individual de valorização da sinceridade e refinado apuro intelectual, a ideia de civilização transformou-se em um estado social diretamente ligado a costumes moderados e ao estabelecimento de relações cordiais entre pessoas de uma mesma classe social, embora o apreço pela sinceridade dos primeiros anos deste conceito tenha perdido força. Como força social, o estado civilizado foi associado ao patamar mais elevado possível a uma sociedade, constituído a partir das experiências da Europa cristã e ocidental nos campos da arte, religião e ciência, de tal modo que o modelo social das elites europeias dos séculos XVIII e XIX seria o arquétipo do ápice civilizatório de todas as sociedades do mundo (ABBAGNANO, 2007).

A partir da análise das fontes através das categorias elencadas (ordem, civilização e progresso), compreendemos o sentido civilizador atribuído à instrução pública na província paraense, bem como no Império brasileiro como um todo, uma vez que toda a importância atribuída a este ramo da administração pública evocava um caráter mais amplo que as ações concretas em si. Em outras palavras, para os discursos oficiais, não se tratava simplesmente de construir escolas, aumentar o número de matrículas, nomear professores para as diversas localidades do vasto território da província ou investir mais recursos na instrução, mas seria o próprio engrandecimento do país através do acesso ilimitado de sua população ao conhecimento, conforme o ideário liberal. No entanto, o caráter civilizador da instrução pública não deve ser compreendido em sua positividade literal apresentada pelos discursos. Faz-se necessário suspeitar e explorar as contradições inerentes a tais discursos, para vislumbrar o real sentido da importância atribuída à instrução pública nos discursos e sua discrepância em relação à adoção de práticas efetivas para sua adoção. As análises dos regulamentos da instrução pública no período delimitado e sua confrontação com discursos oficiais e artigos de jornais sobre instrução torna possível compreender em que sentido a importância atribuída à instrução pública pelos discursos e escritos de políticos e intelectuais locais representa a assimilação de princípios liberais que norteiam os pensamentos de seus autores, de modo que defendem a elevação da província a um patamar civilizado como forma de inserção plena no sistema capitalista internacional. 


\section{Referências}

ABBAGNANO, Nicola. Dicionário de filosofia. 5. ed. São Paulo: Martins Fontes, 2007.

ADORNO, Sérgio. Os aprendizes do poder: o bacharelismo liberal na política brasileira. Rio de Janeiro: Paz e Terra, 1988.

BASTOS, Maria Helena Camara. A formação de professores para o ensino mútuo no Brasil: O "Curso Normal para professores de primeiras letras do Barão de Gérando (1839)". História da Educação. ASPHE/FaE/UFPel, Pelotas (3): 95-119, abr. 1998.

BATES, Henry Walter. Um naturalista no rio Amazonas. São Paulo/Belo Horizonte, EdUSP/Itatiaia, 1979.

BOTO, Carlota. A escola do homem novo: entre o Iluminismo e a Revolução Francesa. São Paulo: Unesp, 1996.

CASTANHA, André Paulo. Pedagogia da moralidade: a Ordem Civilizatória Imperial. Disponível em:http://www.histedbr.fae.unicamp.br/navegando/artigos_frames/artigo_014.html. Acessado em 11/12/2015, $17 \mathrm{~h} 14$.

COSTA, Emília Viotti da. Da Monarquia à República: momentos decisivos. 8. ed. São Paulo: Companhia das Letras, 2008.

Diario do Gram-Pará. Belém, 09 de janeiro de 1860.

ELIAS, Norbert. O processo civilizador, volume 1: uma história dos costumes. 2. ed. Rio de Janeiro: Zahar, 2011.

HOBSBAWM, Eric J. A era do capital. 15. ed. São Paulo: Paz e Terra, 2012.

Lei Provincial $n^{\circ} .203$ de 27 de outubro de 1851. Reformando a instrução primária e secundária.

Lei Provincial $\mathrm{n}^{\circ}$. 348 de 6 de dezembro de 1859. Autoriza o governo da província a reformar a instrução pública.

Lei Provincial $\mathrm{n}^{\circ}$. 664 de 31 de outubro de 1870. Divide o ensino primário em inferior e superior e dá as providências relativas à reforma da instrução primária.

Lei Provincial nº 97 de 28 de junho de 1841. Cria o Liceu Paraense e regula a instrução primária e secundária nesta província.

MACHADO, Maria Cristina Gomes. Rui Barbosa - pensamento e ação: uma análise do projeto modernizador para a sociedade brasileira com base na questão educacional. Campinas: Autores Associados; Rio de Janeiro: Fundação Casa de Rui Barbosa, 2002. (Coleção educação contemporânea)

MARX, Karl\& ENGELS, Friedrich. A ideologia alemã: crítica da mais recente filosofia alemã em seus representantes Feuerbach, B. Bauer e Stirner, e do socialismo alemão em seus diferentes profetas (1845-1846). São Paulo: Boitempo, 2007.

MATTOS, Ilmar Rohloff de. O tempo Saquarema. São Paulo: HUCITEC; Brasília: INL, 1987.

O Liberal do Pará. Belém, 16 de outubro de 1870. 
O Liberal do Pará. Belém, 18 de outubro de 1870.

O Liberal do Pará. Belém, 22 de outubro de 1870.

PENNA, Domingos Soares Ferreira. A Instrução Pública no Pará. O Colombo. Belém, 13 de maio de 1869.

Regulamento para o Liceu Paraense de 8 de novembro de 1851.

SARGES, Maria de Nazaré. Belém: riquezas produzindo a Belle-Époque (1870-1912). Belém: Paka-Tatu, 2000.

WALLACE, Alfred Russel. Viagens pelos rios Amazonas e Negro. São Paulo: Editora da USP, 1979.

\footnotetext{
${ }^{1}$ Artigo elaborado a partir dos resultados da tese de doutorado Ordem, civilização e ciência: o ideário liberal na instrução pública da província do Grão-Pará (1841-1871), defendida em 2016 no âmbito do Doutorado Interinstitucional em Educação celebrado entre a Universidade Estadual de Campinas e a Universidade Federal do Oeste do Pará, com apoio financeiro da Coordenação de Aperfeiçoamento de Pessoal do Ensino Superior (CAPES).

${ }^{2}$ Professor da Universidade Federal do Oeste do Pará - UFOPA.

${ }^{3}$ Professor da Universidade Estadual de Campinas - Unicamp.
}

Recebido: novembro/16

Aprovado: dezembro/16 